\title{
Peranan Otoritas Jasa Keuangan (OJK) Sebagai Lembaga Muhtasib Dalam Industri Keuangan Syariah di Indonesia
}

\author{
Abdul Salam, Syaiful Muhamad Irsyad \\ Fakultas Agama Islam Universitas Alma Ata \\ Jl. Brawijaya No.99 Yogyakarta \\ email: salam.eretan@gmail.com \\ email: syaifulmirsyad@gmail.com
}

\begin{abstract}
In Indonesia, one of the institutions that can be considered a Muhtasib institution in the sharia financial sector is the Financial Services Authority (OJK). As Law Number 21 of 2011, the OJK has the function of organizing an integrated system of regulation and supervision of all activities in the financial services sector which include financial service activities in the Banking sector; financial service activities in the Capital Market sector; and financial service activities in the Insurance, Pension Funds, Financing Institutions and Other Financial Services Institutions sectors, including the Islamic finance industry sector. This study will unravel the extent of the role of the FSA as the Muhtasib in the Islamic finance industry in Indonesia, especially in the regional areas of Central Java and D.I. Yogyakarta.

This research did 2 (two) kinds of research, they are field of study and literature study. The collecting data of this research through observation and non-structured interview. The methode of data collection is conducting interviews with the Central Java OJK, OJK D.I. Yogyakarta.

The conclusion of this study is that the role of the Financial Services Authority (OJK) in Regional Region 3 of Central Java and Yogyakarta as a Muhtasib institution in supervising the Islamic financial industry in Central Java and Yogyakarta is quite significant, although with some notes, including the position of OJK Regional 3 Central Java and DIY Yogyakarta which is only able to reach Islamic financial institutions (LKS) whose head office is located in Central Java and Yogyakarta, while LKS only has branch offices in Central Java and Yogyakarta Yogyakarta. Is the authority of the Regional OJK 3 of Central Java and DIYogyakarta, meaning that it is the domain of the authority of the Central OJK in Jakarta. The problem is if there is a violation or an act that is against the law, then the Regional OJK 3 of Central Java and D.I. Yogyakarta is only reporting or coordinating with the Central OJK. The Financial Services Authority (OJK) in Region 3 of Central Java and Yogyakarta Yogyakarta has carried out its function as an actress in the context of violations of law or criminal acts, in which the OJK has played a function as an investigator and then reported to law enforcement officials (APH) and submitted to the judicial process. However, related to the implementation of the Microfinance Institution Law, OJK has not been able to carry out its function as a constitutional acter in enforcing Article 39 of the LKM Law regarding the existence of BMTs in the community which should abide and comply with licensing regulations under the OJK
\end{abstract}

Keywords: Financial Services Authority, Muhtasib Institution, Sharia Financial Industry

\begin{abstract}
Abstrak
Di Indonesia salah satu institusi yang dapat dianggap sebagai lembaga Muhtasib di sektor lembaga keuangan syariah adalah Otoritas Jasa Keuangan (OJK). Sebagaimana Undang-Undang Nomor 21 tahun 2011, OJK berfungsi menyelenggarakan sistem pengaturan dan pengawasan yang terintegrasi terhadap keseluruhan kegiatan di dalam sektor jasa keuangan yang meliputi kegiatan jasa keuangan di sektor Perbankan; kegiatan jasa keuangan di sektor Pasar Modal; dan kegiatan jasa keuangan di sektor Perasuransian, Dana Pensiun, Lembaga Pembiayaan, dan Lembaga Jasa Keuangan Lainnya, termasuk di dalamnya sektor industri keuangan syariah.
\end{abstract}


Penelitian ini akan mengurai sejauhmana peranan OJK sebagai Muhtasib dalam industri keuangan syariah di Indonesia khususnya diwilayah regional Jawa Tengah dan D.I.Yogyakarta.

Penelitian ini melakukan 2 (dua) jenis penelitian, studi lapangan dan studi literatur. Pengumpulan data dari penelitian ini melalui observasi dan wawancara non-terstruktur. Metode pengumpulan data dengan melakukan wawancara dengan OJK Jawa Tengah, OJK D.I.Yogyakarta.

Kesimpulan dari penelitian ini adalah bahwa Peranan Otoritas Jasa Keuangan (OJK) Wilayah Regional 3 Jawa Tengah dan D.I.Yogyakarta sebagai lembaga Muhtasib dalam mengawasi industri keuangan syariah di wilayah Jawa Tengah dan D.I.Yogyakarta cukup siginifikan, meskipun dengan beberapa catatan, diantaranya adalah posisi OJK Regional 3 Jawa Tengah dan D.I.Yogyakarta yang hanya mampu menjangkau lembaga-lembaga keuangan syariah (LKS) yang kantor pusatnya berkedudukan di Jawa Tengah dan D.I.Yogyakarta sementara LKS yang hanya memiliki kantor cabang di wilayah Jawa Tengah dan D.I.Yogyakarta bukan merupakan kewenangan OJK Regional 3 Jawa Tengah dan D.I.Yogyakarta, artinya itu merupakan ranah kewenangan OJK Pusat di Jakarta. Kendalanya jika terjadi suatu pelanggaran atau perbuatan yang melawan hukum, maka OJK Regional 3 Jawa Tengah dan D.I.Yogyakarta hanya bersifat melaporkan atau berkordinasi dengan OJK Pusat. Otoritas Jasa Keuangan (OJK) Wilayah Regional 3 Jawa Tengah dan D.I.Yogyakarta telah melakukan fungsinya sebagai penindak dalam konteks terjadi pelanggaran hukum atau tindak pidana, di mana OJK telah memainkan fungsi sebagai penyidik untuk kemudian dilaporkan ke aparat penegak hukum $(\mathrm{APH})$ dan diteruksan kepada proses peradilan. Namun demikian terkait dengan implementasi Undang-Undang Lembaga Keuangan Mikro, OJK belum mampu melaksanakan fungsinya sebagai penindak dalam konstek menegakkan Pasal 39 UU LKM terkait eksistensi BMT di masyarakat yang seharusnya tundak dan patuh pada regulasi perijinan dibawah OJK.

Kata Kunci: Otoritas Jasa Keuangan, Lembaga Muhtasib, Industri Keuangan Syariah

\section{PENDAHULUAN}

Dunia bisnis saat ini telah berkembang tanpa batas sehingga manusia mampu menerobos berbagai dimensi kehidupan, terlebih di era globalisasi seperti saat ini. Salah satu ciri bisnis atau perekonomian yang paling menonjol pada era globalisasi adalah moving quickly (Rosyadi dan Ngatino, 2002:1). Perubahan dan pergeseran yang cepat dalam era superindustrialis sekarang telah mengantar umat manusia ke suatu kehidupan "dunia tanpa batas" (borderless world). Keadaan ini digambarkan oleh John Naisbit sebagai perubahan yang dihadapi manusia. Dunia yang dihuni manusia telah berubah menjadi global village (perkampungan global) dengan sistem perekonomian single economy. "The world is moving from trade countries to a single economy. One economy, one market place" (Rosyadi dan Ngatino, 2002:2).

Dalam dunia ekonomi dan bisnis pada masa ini, orang akan terfokus hanya pada bagaimana mencari keuntungan semata (profit oriented) dengan mengenyampingkan nilai-nilai etika dan moralitas bahkan hukum, kalaupun terdapat nilai-nilai sosial tidak lain hal itu dimaknai sebagai nilai promosi untuk menaikan nama baik suatu bisnis.

Kita bisa perhatikan bagaimana iklaniklan di media, yang seolah menawarkan kebaikan dengan desain dan setting kelola yang begitu menawan namun sesungguhnya apa yang diiklankan tidak sesuai fakta yang didapatkan oleh masyarakat (menipu). Kita juga bisa menyaksikan berita-berita di media yang hampir setiap hari mewartakan berbagai praktek bisnis curang. Kita bisa melihat berbagai praktek penipuan terjadi di manamana dengan berbagai modus dan kedok seperti MLM, leasing, arisan, investasi, tenaga kerja, asuransi, koperasi, dan bahkan berkedok agama seperti BMT dan Koperasi Syari'ah (Kedaultan Rakyat, 2 Juli 2009 dan Kompas, 15 Januari 2010).

Dari fakta inilah, sesungguhnya wajar manakala ada pendapat dan mitos yang mengatakan bahwa bisnis itu amoral "the myth of amoral business " seperti yang diungkapkan 
oleh Richard De Goerge (1986) dalam bukunya Business Ethics (Bertens, 2000: 376 - 377). Ia menyebutkan bahwa dalam bisnis, orang menyibukkan diri (busy) dengan jual beli, dengan membuat produk atau menawarkan jasa, dengan merebut pasaran, dengan mencari untung-rugi, tapi orang tidak berurusan dengan etika atau moralitas. Moralitas menjadi urusan individu, tetapi kegiatan bisnis itu sendiri tidak berkaitan langsung dengan etika. Moralitas tidak memiliki relevansi bagi bisnis. Bisnis itu amoral.

Pernyataan Goerge tersebut jika dilihat mengacu pada fakta kegiatan bisnis penganut kapitalisme yang mengedepankan kepentingan individu (eigen behoeften atau self interest) yang bebas dan rasional (a rational man) sebagaimana didengung-dengungkan oleh Adam Smith (1723-1790 M) (Chapra, 2000: 29). self interest merupakan kontribusi terbesar Adam Smith bagi pemikiran ekonomi. Bagi Smith, jika setiap individu dibiarkan memperturutkan kepentingan dirinya, maka "tangan-tangan gaib" (invisible hand) kekuatankekuatan pasar melalui batas-batas yang dibuat oleh proses kompetisi akan mendorong kepentingan masyarakat seluruhnya, sehingga menimbulkan keharmonisan antara kepentingan individu dan umum. Dengan demikian, kepentingan diri yang tak terhambat akan memenuhi kebutuhan-kebutuhan sosial. Menurut Chapra, sakralitas atas self interest inilah yang kemudian menggiring para pelaku bisnis untuk meninggalkan etika dan moralitas serta tanggung jawab (Chapra, 2000: 30).

Konsepsi ini juga mengisyaratkan bahwa dalam bisnis tidak dibutuhkan pengawasan dari siapapun karena semua kegiatan didasarkan pada kepentingan individu atau self interest, termasuk mengebiri peran-peran pemerintah melalui konsep the laissez faire system atau sering disebut sistem pasar bebas yang mengacu pada konsep laisser aller laisser passer (merdeka berbuat merdeka bertindak).

Dari pemikiran inilah menjadi wajar manakala bisnis merupakan kegiatan amoral karena di situ lebih mengedepankan keuntungan kepentingan pribadi, dengan menafikkan kepentingan sosial. Implikasinya semakin hari akan semakin terlihat betapa telah terjadi gap yang begitu mencolok antara kaum kaya yang sering disebut borjuis yakni para pemilik capital (modal) dengan kaum miskin atau proletar, yakni mereka yang menjadi buruh, petani dan kaum pinggiran lainnya. Bisnis di sini menjadi ajang pembunuhan ekonomi, dengan menghalalkan segala cara demi meraih keuntungan yang sebesarbesarnya tanpa ada pengawasan dan kontrol dari siapapun (Enggok, 2004). Bisnis model inilah yang kemudian membenarkan anggapan bahwa manusia adalah serigala bagi sesamanya (homo homini lupus) yakni menjalankan bisnis tak kenal kawan, semua adalah lawan atau musuh yang harus dikalahkan dan dijatuhkan bahkan dikorbankan (Arifin, 2008).

Pada masa sekarang kondisi ini terus berlangsung dan diperparah oleh situasi penegakan hukum (law enforcement) yang lemah. Berbagai aturan hukum dan regulasi banyak yang tidak jalan sehingga aturan hanya berada pada lembaran-lembaran kertas yang tidak memiliki kekuatan mempengaruhi (mandul). Dalam situasi seperti ini maka lumrah ketika sebagian pihak meragukan efektifitas penegakan etika bisnis di Indonesia yang secara normatif levelnya di atas aturan hukum formal. Namun demikian keraguan ini tentu bukan berarti etika bisnis tidak dapat ditegakkan (Lukviarman, 2004).

Jika dicermati lebih mendalam sesungguhnya etika merupakan satu bagian yang sama sekali tidak bisa dipisahkan dari kehidupan masyarakat sehari-hari, khususnya kehidupan bisnis. Menurut Triyuwono (2006: 73-74), ada beberapa alasan untuk mendukung pernyataan ini. Pertama, masyarakat pada dasarnya dibangun atas dasar aturan-aturan etika. Bisnis misalnya, harus beroperasi dalam tatanan sosial yang dalam beberapa metodenya sama etisnya dengan aturan hukum, politik, ekonomi dan lain sebagainya yang melingkupinya. Dengan demikian, keputusan-keputusan bisnis dapat dibatasi oleh lingkungan etikanya, seperti undangundang, politik, ekonomi, dan lain-lain. Jadi, jelas di sini bahwa bisnis tidak dapat beroperasi tanpa memperhatikan aturan-aturan yang ditetapkan oleh masyarakat setempat.

Kedua, bisnis merupakan sebuah kekuatan yang mempunyai pengaruh sangat besar terhadap kehidupan masyarakat, 
bahkan kekuatannya sebanding dengan kekuatan agama dan politik. Populasi yang bekerja dalam sebuah masyarakat, hampir semuanya menggantungkan diri dalam bisnis untuk sumber kehidupannya, dan sisanya menggantungkan diri sebagai konsumen. Bisnis bukan merupakan kekuatan yang statis, tetapi sebaliknya ia merupakan sebuah kekuatan yang terus berkembang baik dalam bentuk kuantitas maupun kualitas, ia tidak terbatas pada satu daerah, tetapi sebaliknya menjelajahi seluruh belahan bumi. Perusahaan multinasional tumbuh semakin hari semakin besar menjelajah semua Negara dengan pasar barang, jasa dan uang yang semakin global bahkan sulit mengendalikan kekuatan dan gerak dinamis bisnis.

Ketiga, berkenaan dengan manusia sebagai agen yang secara aktif menjalankan bisnis. Manusia, khususnya manajer adalah pribadi yang secara sadar mengendalikan dan menjalankan bisnis. Untuk menjalankan bisnis, seorang manajer dituntut untuk memiliki profesionalisme yang tinggi. Tanpa bekal profesionalisme ini mustahil bisnis yang dijalankannya akan mampu bertahan hidup lama. Bagi seorang manajer yang profesioal, kemampuan intelektual yang tinggi dan tanggungjawab yang besar merupakan bekal utama yang sangat bernilai dalam menjalankan bisnis. Hal ini demikian, karena semakin besar dan kompleks keadaan suatu bisnis, maka semakin besar pula tuntutan untuk memiliki intelektual danilmu pengetahuan yang memadai, demikian pula akan tuntutan tanggungjawab. Manajer, dalam membuat rencana strategis, mengorganisir sumberdaya-sumberdaya yang dimilikinya dan mengendalikan operasi bisnis, dituntut tanggungjawab yang besar. Karena apa yang dilakukan manajer sebetulnya bukan merupakan pekerjaan teknis, tetapi menyangkut tanggungjawab terhadap orang lain. Manajer, dalam hal ini, harus menjaga modal yang ditanamkan oleh investor, menjaga kelestarian alam, melindungi konsumen dari produk atau jasa yang merugikan atau membahayakan, dan menjaga kesehatan dan keselamatan buruh dan pegawai. Pendek kata, seorang manajer harus secara bertanggungjawab memperhatikan kesejahteraan masyarakat umum termasuk keseimbangan lingkungan hidup.
Dari ketiga alasan di atas, dapat dilihat bahwa kebutuhan akan aplikasi etika dalam bisnis pada dasarnya terletak pada skala makro dan mikro. Pada skala makro, hakikat masyarakat itu sendiri yang tidak bisa terlepas dari sistem nilai etika (misalnya, sistem ekonomi, politik, hukum, sosial dan agama). Sementara dalam skala mikro, kapasitas manusia sebagai individu yang memiliki kemampuan untuk membangun dan menciptakan dunia realitas, yaitu realitas dengan jaringan sistem nilai yang mengikat dan memilih kehidupan individu-individu dalam masyarakat yang luas dan majemuk. Ketika sebuah realitas telah tercipta, namun tanpa didasari nilai-nilai etika, maka realitas yang diciptakan tersebut akan menjaring kehidupan individu-individu dalam masyarakat ke dalam jaringan-jaringan tanpa nilai etika. Akibatnya, tatanan kehidupan sosial akan menjadi rusak dan korup, dan masyarakat yang bersangkutan pada hakikatnya telah "mati".

Untuk menyelamatkan masyarakat dari "kematian" tersebut, maka nilai-nilai etika harus terus dijaga dan ditegakan dalam setiap lini kehidupan, termasuk kehidupan bisnis. Nilai-nilai etika bisnis hanya dapat ditegakkan jika ada kombinasi sinergis antara adanya kesadaran dari pelaku ekonomi dan bisnis, konsumen, regulasi dan pengawasan yang tegas dan konsisten dari pemerintah selaku regulator dan pembuat kebijakan. Kombinasi sinergis ini harus mengacu pada kesadaran bersama akan pentingnya etika bisnis sebagai sebuah standar acuan moral dalam penyelenggaraan praktik bisnis (Haryani dan Subkhan, 2006 : 19).

Di sinilah kemudian pentingnya pelembagaan etika bisnis yang tidak saja menjadi pengetahuan atau kesadaran orang perorang, namun melembaga dalam institusi bisnis dan pemerintahan. Secara internal berbagai bentuk pelembagaan etika bisnis kini memiliki beragam nama seperti code of conduct, corporate social responsibility, good corporate governance atau code of ethics (Lukviarman, 2004).

Menurut Haryani dan Subkhan pelembagaan etika bisnis dapat dilihat pada dua tingkatan, yaitu tingkatan pelaku dan tingkatan masyarakat. Pada tingkatan pelaku dapat dilembagakan dalam institusi, organisasi, asosiasi perusahaan. Sedangkan pada tingkatan 
masyarakat dapat dilembagakan dalam masyarakat lokal maupun global. Bentuk konkret pelembagaan etika ini ada dua yakni aturan tertulis yang menyangkut implementasi prinsip-prinsip etika bisnis dan adanya komite yang ditunjuk untuk mengawal implementasi prinsip-prinsip etika bisnis. Di tingkat institusi ada beberapa aturan tertulis berisi etika bisnis seperti pemberlakuan pedoman perilaku di beberapa perusahaan. Pedoman perilaku ini menjadi panduan bagi semua stakeholders dan stockholders baik pihak internal (karyawan) maupun pihak eksternal seperti pemegang saham, perusahaan afiliasi, prinsipal, investor, pelanggan, pemasok, pemerintah, masyarakat, serta lingkungan sekitar. Di dalamnya dijelaskan apa saja yang boleh dan tidak boleh dilakukan oleh perusahaan dalam konteks hubungan dengan stakeholders dan stockholders (Lukviarman, 2004).

Pelembagaan etika bisnis ini sesungguhnya telah ada sejak 14-15 abad lalu, terutama di dunia bisnis kaum muslimin pada waktu itu. Di masa perkembangan Islam di Madinah (622-632 M) di mana Nabi Muhammad SAW menjadi pemimpinnya, telah terbentuk satu institusi yang disebut hisbah. Hisbah adalah institusi yang bertugas mengontrol etika masyarakat dalam kehidupan religiusitas, sosial dan ekonomi. Hisbah dikelola oleh petugas yang memiliki integritas dan kapabilitas yang sangat terpercaya dan mumpuni. Orang yang melaksanakan tugas hisbah disebut dengan Muhtasib. Pada masa itu, Nabi Muhammad SAW merupakan orang yang menjadi Muhtasib pertama di Madinah. Sebagai Muhtasib yang pertama, Nabi Muhammad SAW telah meletakkan pondasi bagi penegakan etika masyarakat. Beliau membangun suatu bangunan etika dan perangkatnya untuk dijadikan aturan main dalam kehidupan sehari-hari termasuk dalam kegiatan bisnis dan ekonomi (Ibn Taymiah,, Holland 1982: 47).

Dengan mendasarkan diri pada AlQur'an sebagai sumber prinsip etika, beliau mengaplikasikan ke dalam kehidupan beliau melalui berbagai sunnahnya baik qauliyah (perkataan), fi'liyah (perbuatan) maupun taqririyah (penetapan) untuk dijadikan pedoman bagi masyarakat di Madinah. Beliau membuat aturan ketat bagaimana berbisnis yang baik dan beretika, dengan memperhatikan lingkungan sosial kemasyarakatan. Sunnahsunnah itulah yang kemudian menjadi pedoman kode etik atau code of conduct bagi lembaga hisbah dalam menjalankan tugastugasnya. Setelah code of conduct tersebut dapat terimplementasikan dengan baik, Nabi Muhammad SAW menyerahkan lembaga hisbah untuk dikelola oleh para sahabatnya dengan menunjuk Umar Ibn Khattab sebagai Muhtasib di Madinah dan Said ibn Said Ibn alAsh Ibn Umayah sebagai Muhtasib di Makkan (A. Khan, 1982).

Pelembagaan etika bisnis ini kemudian terus dikembangkan pada masa-masa pemerintahan Islam berikutnya yakni dari masa Khulafa ar-Rasyidin (632-661 M), Bani Umayah (661-750 M), Bani Abbasiyah (7501258 M), Bani Fathimiyah di Mesir (909-1171 M), Bani Umayah di Andalusia Spanyol (929$1031 \mathrm{M}$ ) hingga Kesultanan Turki Utsmani (1299-1923 M). Peran strategis dan efektifitas dari lembaga hisbah ini dalam melaksanakan kontrol terhadap etika bisnis dan pelayanan publik, menarik perhatian masyarakat Barat terutama Eropa untuk mengadopsi dan mengelaborasi konsep lembaga hisbah tersebut (Dwidjowijoto, et al, 2008: 17 - 17 ).

Di Indonesia salah satu institusi yang dapat dianggap sebagai lembaga Muhtasib di sektor lembaga keuangan syariah adalah Otoritas Jasa Keuangan (OJK). Sebagaimana Undang-Undang Nomor 21 tahun 2011, OJK berfungsi menyelenggarakan sistem pengaturan dan pengawasan yang terintegrasi terhadap keseluruhan kegiatan di dalam sektor jasa keuangan yang meliputi kegiatan jasa keuangan di sektor Perbankan; kegiatan jasa keuangan di sektor Pasar Modal; dan kegiatan jasa keuangan di sektor Perasuransian, Dana Pensiun, Lembaga Pembiayaan, dan Lembaga Jasa Keuangan Lainnya, termasuk di dalamnya sektor industri keuangan syariah. Penelitian ini akan mengurai sejauhmana peranan OJK sebagai lembaga Muhtasib dalam industri keuangan syariah di Indonesia dan sejauhmana OJK melakukan penindakan terhadap lembaga keuangan syariah yang melakukan pelanggaran etika bisnis maupun pelanggaran hukum khususnya di wilayah regional Jawa Tengah dan D.I.Yogyakarta. 


\section{PEMBAHASAN}

Tinjauan Umum OJK Jawa Tengah dan D.I.Yogyakarta

OJK Jawa Tengah dan D.I.Yogyakarta merupakan kantor regional 3 (KR3) yang membawahi kantor-kantor perwakilan di propinsi Jawa Tengah dan D.I.Yogyakarta, yang meliputi Tegal, Purwokerto, Surakarta dan Yogyakarta. OJK KR3 Jawa Tengah didirikan pada tahun 2014 dengan berkantor di Semarang, Jawa Tengah.

Keberadaan OJK diharapkan bisa memenuhi harapan masyarakat, yakni untuk mendorong terciptanya Sektor Jasa Keuangan yang berdaya tahan tinggi untuk mewujudkan stabilitas perekonomian dan mendukung pembangunan yang berkelanjutan, serta mengoptimalkan peran Sektor Jasa Keuangan dalam meningkatkan kegiatan perekonomian termasuk peningkatan akses keuangan dan kemandirian finansial masyarakat serta mendukung upaya peningkatan pemerataan dalam pembangunan.

Hubungan kerjasama OJK dengan Pemda sangat terkait dengan amanat UndangUndang Nomor 1 Tahun 2013 tentang Lembaga Keuangan Mikro (LKM), yang memberikan mandat kepada OJK untuk melaksanakan pembinaan, pengaturan dan pengawasan Lembaga Keuangan Mikro di seluruh penjuru Tanah Air mulai 2015. Untuk pelaksanaan tugas pembinaan, pengaturan dan pengawasan LKM, OJK berkoordinasi dengan Pemerintah Daerah, Kementerian Dalam Negeri, dan

Tabel 1. Daftar Bank Umum Syariah (BUS) per Agustus 2018

\begin{tabular}{ll}
\hline No & Nama Bank Umum Syariah (BUS) \\
\hline 1 & PT. Bank Aceh Syariah \\
2 & PT. Bank Muamalat Indonesia \\
3 & PT. Bank Victoria Syariah \\
4 & PT. Bank BRI Syariah \\
5 & PT. Bank Jabar Banten Syariah \\
6 & PT. Bank BNI Syariah \\
7 & PT. Bank Syariah Mandiri \\
8 & PT. Bank Mega Syariah \\
9 & PT. Bank Panin Dubai Syariah \\
10 & PT. Bank Syariah Bukopin \\
11 & PT. BCA Syariah \\
12 & PT. Bank Tabungan Pensiunan Nasional Syariah \\
13 & PT. Maybank Syariah Indonesia \\
\hline
\end{tabular}

Sumber: SPS (Statistik Perbankan Syariah) OJK
Kementerian Negara Koperasi dan Usaha Kecil Menengah.

Berdasarkan data OJK, jumlah bank syariah hingga Agustus 2018 terdapat 13 Bank Umum Syariah (BUS), 21 Unit Usaha Syariah (UUS) dan 168 Bank Pembiayaan Rakyat Syariah (BPRS).

Dari data tersebut terlihat bahwa ada 12 BUS berkedudukan (kantor pusat) di Jakarta dan hanya 1 BUS yang bekedudukan di luar Jakarta yakni PT Bank Aceh Syariah yang berkantor pusat di Banda Aceh, Propinsi Nangroe Aceh Darussalam.

\section{Tabel 2. Daftar Unit Usaha Syariah (UUS) pada} Bank Umum Konvensional

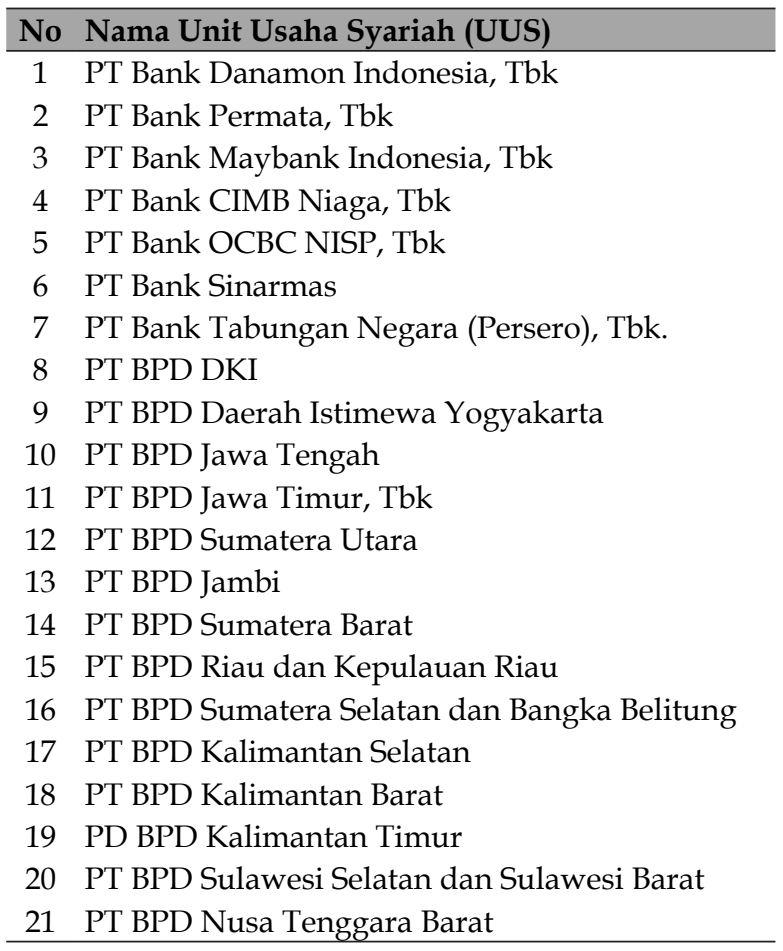

Sumber: SPS (Statistik Perbankan Syariah) OJK

Sementara untuk Industri Keuangan Non Bank (IKNB) Syariah hingga September 2018 terdapat 78 perusahaan yang terdiri dari 13 Perusahaan Asuransi Syariah, 7 Lembaga Pembiayaan Syariah, 1 Dana Pensiun Syariah, 6 Lembaga Jasa Keuangan Khusus Syariah dan 51 Lembaga Keuangan Mikro Syariah (LKMS).

Di Jawa Tengah terdapat 26 BPRS, di D.I.Yogyakarta terdapat 12 BPRS. Untuk INKB Syariah tercatat hingga Agustus 2018, terdapat 14 LKMS di Jawa Tengah dan 3 LKMS di D.I.Yogyakarta dan 1 Jasa Gadai Syariah di Jawa Tengah (Nita, 2018) 


\begin{tabular}{lc}
\hline \multicolumn{1}{c}{ Keterangan } & $\begin{array}{c}\text { Jumlah Industri } \\
\text { Syariah (Unit) } \\
\text { Number of Sharia } \\
\text { Industries (Units) }\end{array}$ \\
\hline 1. Asuransi Syariah & 13 \\
a. Asuransi Jiwa Syariah & 7 \\
b. Asuransi Umum Syariah & 5 \\
c. Reasuransi Syariah & 1 \\
2. Lembaga Pembiayaan & \\
Syariah & 7 \\
a. Perusahaan Pembiayaan & \\
$\quad$ Syariah & 3 \\
b. Perusahaan Modal Ventura & \\
$\quad$ Syariah & 4 \\
c. Perusahaan Pembiayaan & \\
$\quad$ Infrastruktur Syariah & - \\
3. Dana Pensiun & 1 \\
a. DPPK-PPMP Syariah & - \\
b. DPPK-PPIP Syariah & - \\
c. DPLK Syariah & 1 \\
4. Lembaga Jasa Keuangan & \\
Khusus Syariah & \\
a. Penjaminan Syariah & \\
b. LPEI Syariah & \\
c. Pergadaian Syariah & \\
d. Perusahaan Pembiayaan & \\
$\quad$ Sekunder Perumahan & \\
5. LembP) Syariah & \\
Syariah & \\
\hline
\end{tabular}

Sumber: hasil wawancara

\section{Sebaran BPRS di Indonesia}

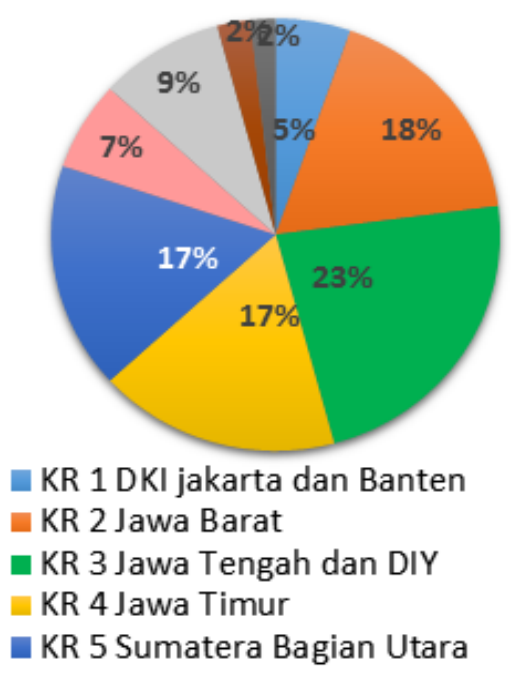

Menurut Kepala OJK Regional 3 Jawa Tengah dan DIY, Aman Santosa, sektor perbankan Jawa Tengah posisi September 2018 mengalami pertumbuhan yang cukup baik. Terlihat dari pertumbuhan aset sebesar Rp
403,77 triliun atau mencapai 8,16 persen yoy, kredit sebesar Rp 294,38 triliun atau mencapai 8,55 persen, dan dana pihak ketiga yang tumbuh sebesar Rp 305,91 triliun atau tumbuh sebesar 9,82 persen. Pertumbuhan dana pihak ketiga ini lebih tinggi dibandingkan nasional yang sebesar 6,65 persen.

Sementara perkembangan perbankan syariah di Jawa Tengah, tercatat pembiayaan yang disalurkan sebesar Rp 20,12 triliun atau mengalami pertumbuhan 18,44 persen yoy. Pertumbuhan pembiayaan itu lebih tinggi dibandingkan nasional yang tumbuh sebesar 14,35 persen. Share pembiayaan tersebut berkontribusi terhadap nasional 6,84 persen, hal ini seiring dengan kualitas pembiayaan yang disalurkan lebih baik dibandingkan nasional yang ditunjukkan dengan NPF sebesar 2,68 persen sedangkan nasional sebesar 3,45 persen.

Lebih rinci, Aman menyampaikan, penyaluran kredit per jenis penggunaan sudah efektif terlihat pada penyaluran terbesar pada kredit modal kerja sebesar Rp 161,5 triliun atau tumbuh sebesar 10,66 persen yoy dengan share sebesar 54,87 persen. Sedangkan penyaluran kredit per sektor ekonomi terbesar yaitu pada sektor perdagangan besar, dan eceran yang tumbuh sebesar Rp 96 triliun atau tumbuh sebesar 10,42 persen.

Di sektor lainnya, perkembangan Industri Jasa Keuangan Non Bank di Jawa Tengah, mencatatkan pembiayaan pada perusahaan pembiayaan sebesar Rp 49,74 triliun, meningkat 6,62 persen yoy dengan share terhadap nasional sebesar 11,01 persen. Menurut Aman, kualitas pembiayaan yang disalurkan sudah cukup baik terlihat dari NPF sebesar 1,34 persen lebih rendah dibanding NPF nasional sebesar 3,17 persen. Selain itu data mengenai Bank Wakaf Mikro, terdapat 9 Bank Wakaf Mikro yang telah diresmikan di Jawa Tengah dan DIY, 7 di antaranya ada di Jawa Tengah.

Menurut Aman, perkembangan sektor pasar modal jumlah single investor identity (SID) di Jawa Tengah tercatat sebanyak 72.675 meningkat 33,57 persen yoy, dengan nilai transaksi saham sebesar $\operatorname{Rp} 3,18$ triliun.

Sementara terkait perkembangan pembiayaan baru melalui Peer-to-Peer Lending Financial Technology (Fintech), berkembang 
cukup signifikan, di mana hingga September 2018 terdapat 73 perusahaan terdaftar dengan 1 perusahaan yang berizin. Dari sisi outstanding pembiayaan tercatat sebesar Rp 708,01 miliar dengan 142.367 borrower, sedangkan dari sisi lender sebesar Rp 151,18 miliar dengan jumlah lender sebanyak 12.450 orang. Lalu dari perusahaan pergadaian, tercatat jumlah perusahaan sebanyak 58 perusahaan secara nasional, 7 di antaranya berada di Jawa Tengah. Peran OJK Sebagai Muhtasib Dalam Industri Keuangan Syariah Di Jawa Tengah dan D.I.Yogyakarta

Secara normatif, OJK memiliki tiga visi utama yakni: 1). Menjadi lembaga pengawas industri jasa keuangan yang terpercaya; 2). Mampu mewujudkan industry jasa keuangan menjadi pilar perekonomian nasional yang berdaya saing global serta dapat memajukan kesejahteraan umum, dan 3). Melindungi kepentingan konsumen dan masyarakat.

Adapun misi utama OJK adalah: a) Mewujudkan terselenggaranya seluruh kegiatan di dalam sektor jasa keuangan secara teratur, adil, transparan, dan akuntabel; b). Mewujudkan sistem keuangan yang tumbuh secara berkelanjutan dan stabil, dan c) Melindungi kepentingan konsumen dan masyarakat.

Sejak berdiri dan hingga kini OJK telah memainkan peranannya secara efektif terutama sebagai lembaga pengawas industri jasa keuangan dengan mengcreate berbagai aturan dalam rangka mewujudkan sektor jasa keuangan yang teratur, adil, transparan, dan akuntabel. OJK selama 2012 - triwulan I-2017 telah menerbitkan 202 Peraturan Otoritas Jasa Keuangan (POJK) dan 159Surat Edaran Otoritas Jasa Keuangan (SEOJK) untuk mengatur sektor jasa keuangan. Terkait dengan POJK, telah diterbitkan 59 POJK yang mengatur bidang perbankan, 77 POJK mengatur bidang Pasar Modal, 59 POJK mengatur bidang IKNB dan 7 POJK mengatur Edukasi dan Perlindungan Konsumen, Tata Cara Pungutan, Penyidikan Tindak Pidana, Financial Technology (Fintech), serta Program Anti Pencucian Uang dan Pendanaan Terorisme.

OJK juga menerbitkan Master Plan Sektor Jasa Keuangan Indonesia (MPSJKI) yang menjadi acuan arah pengembangan sektor jasa keuangan tahun 2015-2019. Master
Plan ini terdiri dari tiga pilar utama yaitu: mengoptimalkan peran sektor jasa keuangan dalam mendukung percepatan pertumbuhan ekonomi nasional (Pilar Kontributif); menjaga stabilitas sistem keuangan sebagai landasan bagi pembangunan yang berkelanjutan (Pilar Stabil); dan mewujudkan kemandirian finansial masyarakat serta mendukung upaya peningkatan pemerataan dalam pembangunan (Pilar Inklusif).

Terkait penguatan ketahanan sektor jasa keuangan, OJK melakukan beberapa inisiatif di antaranya penguatan pengawasan terhadap konglomerasi keuangan, pengembangan Sistem Pengelolaan Investasi Terpadu (S-Invest), Sistem Pemantauan Efek Terintegrasi (SIPETRO), Electronic Trading Platform (ETP), Sistem Online Trading Syariah (SOTS), pengawasan berbasis risiko dan pengawasan Market Conduct, peluncuran Global Master Repurchase Agreement (GMRA), dan Sistem Perizinan Terintegrasi (SPRINT) yang dapat mempercepat proses perizinan. SPRINT telah diimplementasikan pada perizinan bancassurance, penjualan Reksa Dana melalui bank selaku agen penjual efek Reksa Dana serta pendaftaran akuntan publik.

Dalam rangka memfasilitasi pembiayaan pendanaan pembangunan berkelanjutan serta adaptasi dan mitigasi perubahan iklim, OJK bersama dengan Kementerian Lingkungan Hidup dan Kehutanan (KLHK) meluncurkan Roadmap Keuangan Berkelanjutan (RKB).

Sebagai lembaga pengawas yang independen, OJK dalam persepktif kelembagaan ekonomi Islam, dapat dikategorikan sebagai Lembaga Muhtasib dalam industri jasa keuangan. Menurut Ibn Taimiyah, paling tidak ada dua fungsi Muhtasib yakni, pertama, sebuah sistem yang secara umum digambarkan pelaksanaan kebajikan dan kewajiban oleh Muhtashib dan berkaitan dengan aspek agama dan yuridis dalam pengurusannya, dan kedua, digambarkan sebagai praktek dan tehnik pengawasan secara detail. Pengawasan secara prinsip dilakukan atas berbagai bentuk produk bisnis dan perdagangan, bahkan juga mencakup tata administrasi dan kualitas maupun standar produk.

Merujuk visi misi serta tugas pokok dan fungsinya sebagaimana disebutkan 
dalam Undang-undang, maka sudah tepat OJK disebut sebagai Muhtasib, terlebih OJK mengakomodir bahkan membuat sistem pengawasan dan perlindungan terhadap industri keuangan syariah baik industri perbankan syariah maupun industri non perbankan syariah.

Sebagai Muhtasib, OJK tidak saja mengawasi dari sisi ketaatan terhadap regulasi tetapi juga ketaatan terhadap aspek-aspek syar' inya melalui penguatan pengawasan syariah, baik langsung dengan membuat peraturan OJK (POJK) maupun akomodasi terhadap fatwa-fatwa yang dikeluarkan oleh Dewan Syariah Nasional Majelis Ulama Indonesia (DSN MUI).

Selain mengatur dan mengawasi, tugas pokok OJK yaitu perlindungan konsumen. Sepanjang 2017, Layanan Konsumen OJK menerima 24.771 layanan yang terdiri dari 5.236 layanan informasi $(21,14 \%), 19.444$ layanan pertanyaan $(78,50 \%)$, dan 91 layanan pengaduan $(0,37 \%)$. Jumlah seluruh layanan tersebut mengalami penurunan jika dibandingkan dengan jumlah layanan 2016, yaitu turun sebanyak 3.803 layanan $(18,14 \%)$.

Data OJK Regional Jawa Tengah dan D.I.Yogyakarta sampai dengan September 2018, jumlah pengaduan masyarakat sebanyak 277 yang didominasi pengaduan terhadap perbankan sebanyak 41,50 persen, diikuti perusahaan pembiayaan sebesar 13,43 persen.

Untuk memberikan kemudahan akses kepada Konsumen dan masyarakat, OJK menyediakan beberapa akses kanal layanan yang meliputi: a) Telepon Contact Center atau yang sering disebut dengan Layanan Konsumen OJK, atau Layanan 1500-655, b) Email konsumen dengan alamat : konsumen@ ojk.go.id, c) Formulir pengaduan elektronik yang dapat diakses melalui situs : konsumen. ojk.go.id/ FormPengaduan, d) Mobile application sikapiuangmu, e) Surat tertulis, dan f) Penerimaan layanan secara langsung (walk-in).

Dari keseluruhan jumlah layanan yang diterima oleh Layanan Konsumen OJK, jika dikategorikan per masing-masing sektor industri jasa keuangan, maka didapatkan informasi sebagai berikut: a. 9.734 layanan $(39,30 \%)$ sektor Perbankan, b. 4.049 layanan (16.35\%) sektor Perasuransian, c. 2.627 layanan $(10,61 \%)$ Lembaga Pembiayaan, d. 120 layanan $(0,48 \%)$ Dana Pensiun, e. 477 layanan $(1,93 \%)$ Lembaga Jasa Keuangan lainnya, f. 1.151 layanan (4,65\%) Pasar Modal, dan g. 6.613 layanan $(26,70 \%)$ non Lembaga Jasa Keuangan.

OJK meletakkan fundamental prinsip perlindungan konsumen yang mengacu kepada international best practises yang terdiri atas (1) Transparansi (2) Keadilan (3) Keandalan (4) Kerahasiaan Data/Informasi (5) Penanganan Pengaduan dan penyelesaian sengketa konsumen secara sederhana, cepat dan terjangkau. Strategi Perlindungan Konsumen Keuangan ini ditujukan untuk menciptakan budaya treat customer fairly yang mengedepankan prinsip keseimbangan yaitu

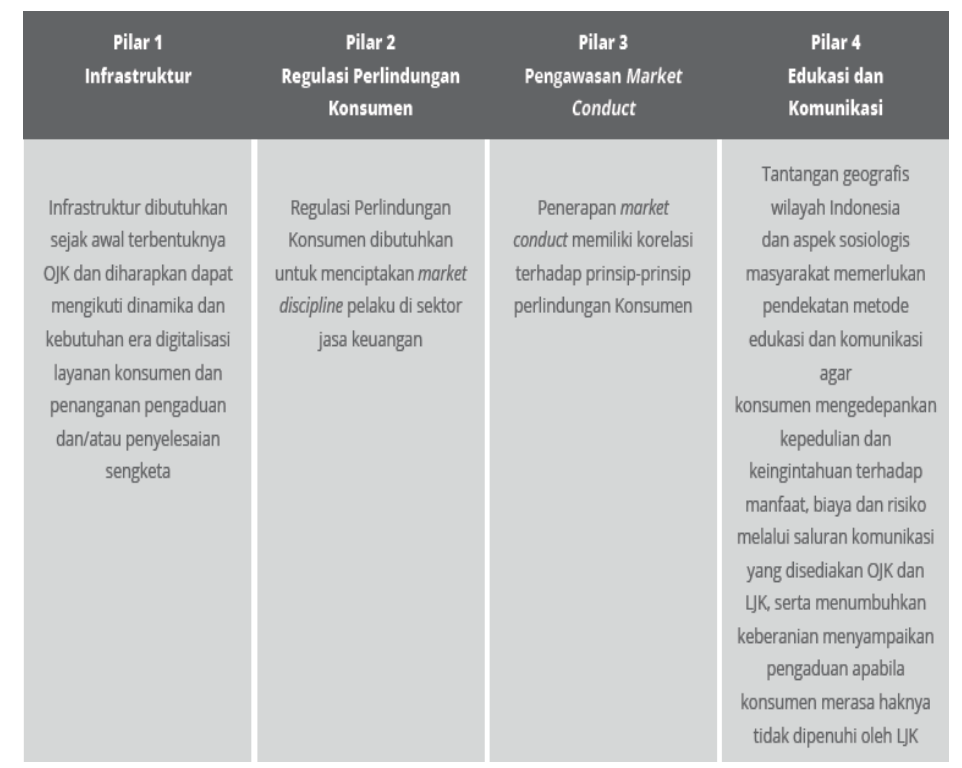


kepercayaan konsumen dan masyarakat terhadap produk jasa keuangan yang ditawarkan (market confidence) dan terwujudnya level playing field antara konsumen dan lembaga jasa keuangan.

OJK telah menerbitkan empat pilar utama perlindungan konsumen, yakni: Pilar 1 Infrastruktur, Pilar 2 Regulasi Perlindungan Konsumen, Pilar 3 Pengawasan Market Conduct dan Pilar 4 Edukasi dan Komunikasi.

Sesuai kerangka implementasi pengawasan market conduct, pelaksanaan pemantauan dan analisis perlindungan konsumen oleh OJK menggunakan tools pemeriksaan thematic surveillance secara onsite melalui hasil kolaborasi antara Satuan Kerja yang membidangi pengawasan market conduct dengan Satuan Kerja pengawas prudential. Sinergi ini hasilnya diharapkan akan lebih lengkap dan komprehensif. Pengawasan market conduct fokus pada interaksi antara konsumen dengan Lembaga Jasa Keuangan (aspek kualitatif). Sementara itu, pengawasan prudensial tetap fokus pada tingkat kesehatan LJK (aspek kuantitatif).

Sebagai pilot project, OJK melakukan pemeriksaan thematic surveillance terhadap tujuh Bank Pembangunan Daerah (BPD), satu Bank Umum Konvensional, serta satu Bank Umum Syariah. Pemeriksaan tersebut mengambil tema "Aspek Perlindungan Konsumen Pada Perjanjian Baku" dengan melihat klausula/ konten dan format perjanjian baku untuk memastikan kepatuhan LJK terhadap POJK No. 1 Tahun 2013 baik dari aspek kebijakan, implementasi serta evaluasi terhadap perjanjian baku dengan mempertimbangkan product life cycle.

Kerangka kegiatan lainnya adalah Operasi Intelijen Pasar (OIP) dengan cakupan kegiatan yaitu memetakan isu perlindungan konsumen terkait dengan praktik pemasaran asuransi jiwa dengan metode Multi Level Marketing (MLM). Tema ini sejatinya telah teridentifikasi dari kegiatan thematic surveillance sebelumnya mengenai unit link dan telah dilaksanakan dengan mengambil sampling di kota Medan, Makassar, Yogyakarta dan Jakarta.

Isu kerawanan konsumen yang menjadi perhatian, antara lain:

1. Bisnis lebih fokus pada perluasan jaringan untuk mendapatkan fee dibandingkan penjualan manfaat produk unit link. Oleh karena itu, penjelasan yang diberikan pemasar lebih banyak mengenai bisnis jaringan dibanding manfaat, biaya, dan risiko produk;

2. Pemasar maupun calon nasabah yang nantinya akan menjadi tenaga pemasar tidak bersertifikasi AAJI sebagai justifikasi atau pembuktian atas pernyataan telah memiliki tingkat literasi yang memadai terkait produk unit link. Hal ini tercermin dari penjelasan pemasar yang belum terstandar dan rata-rata belum memiliki sertifikasi Asosiasi Asuransi Jiwa Indonesia (AAJI); dan

3. Mekanisme penjualan menyerupai MLM dan sejauh ini tidak memiliki SIUPL (Surat Izin Usaha Penjualan Langsung).

OJK melakukan pemantauan iklan melalui Sistem Informasi Pelaporan Market Intelijen (SIPMI) yang menghimpun iklan terkait produk dan atau layanan jasa keuangan pada sekitar 82 media cetak dan online yang tersebar di seluruh wilayah Indonesia. Pemantauan tersebut dilaksanakan untuk menganalisis dugaan pelanggaran pada iklan penawaran produk dan layanan jasa keuangan berdasarkan POJK Nomor 1/POJK.07/2013 tentang Perlindungan Konsumen Sektor Jasa Keuangan dan SEOJK Nomor 12/SEOJK.07/2014 tentang Penyampaian Informasi dalam Rangka Pemasaran Produk dan/atau Layanan Jasa Keuangan.

Kriteria dalam pemantauan iklan adalah jelas, jujur, akurat dan tidak menyesatkan. Di samping itu, terdapat kriteria pencantuman kalimat bahwa "LJK diatur dan diawasi oleh OJK". Sepanjang 2017, terdapat 827 iklan yang berkaitan dengan produk dan atau jasa keuangan dengan grafik jumlah iklan produk dan atau layanan jasa keuangan per sektor sebagai berikut:

Dari jumlah tersebut, terdapat 427 iklan yang diduga melanggar ketentuan sebagaimana tertuang dalam POJK Nomor 1/ POJK.07/2013 tentang Perlindungan Konsumen Sektor Jasa Keuangan dan SEOJK Nomor 12/SEOJK.07/2014 tentang Penyampaian Informasi dalam Rangka Pemasaran Produk dan/atau Layanan Jasa Keuangan. Tren dugaan pelanggaran iklan per bulan dapat dilihat pada grafik di bawah ini: 


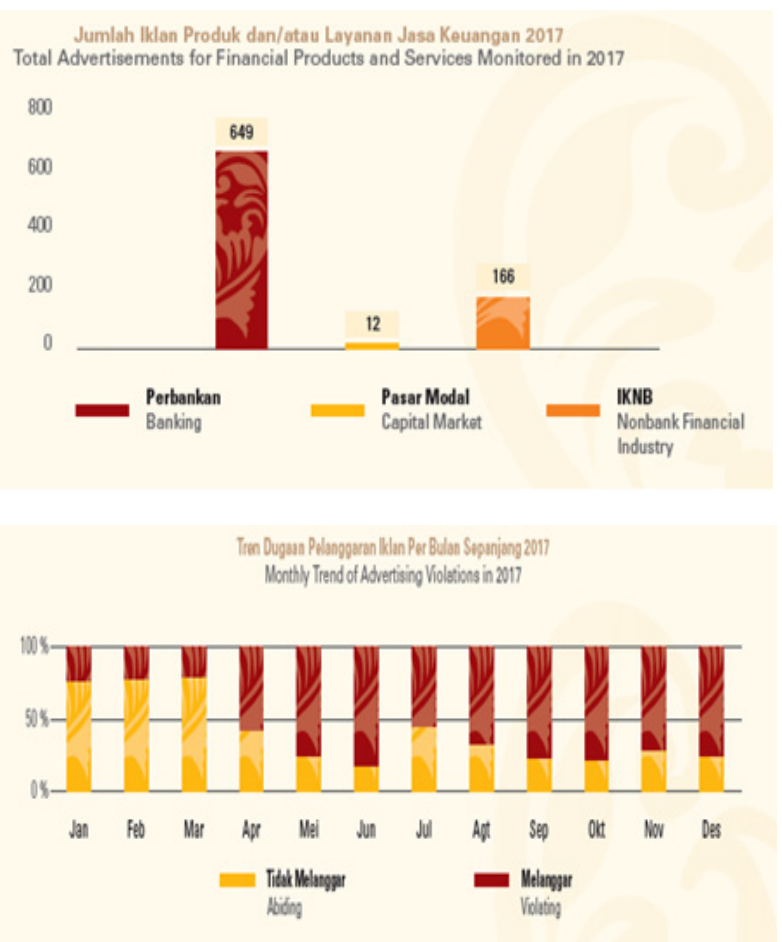

Kategori paling banyak dilanggar sesuai dengan beleid yang berlaku dapat dilihat pada grafik di bawah ini:

Kategori lain-lain dimana LJK harus mencantumkan bahwa lembaga keuangan terkait terdaftar dan diawasi oleh OJK juga menjadi salah satu kategori dengan dugaan pelanggaran terbanyak. Padahal, pencantuman ini menjadi salah satu tolak ukur masyarakat dalam memilih produk dan jasa keuangan resmi. Sementara itu, dugaan pelanggaran kategori tidak akurat dan menyesatkan cenderung rendah. Hal ini diduga terjadi karena maraknya klaim produk dan/ atau layanan keuangan terbaik oleh LJK serta persaingan yang semakin ketat. Untuk mengidentifikasi kepatuhan LJK, sepuluh besar produk yang diduga melakukan pelanggaran dapat dilihat pada grafik di bawah ini:

Dari grafik dapat dilihat bahwa dugaan pelanggaran didominasi oleh produk perbankan. Hal ini diduga terjadi karena selain variasi produk perbankan lebih beragam, intensitas iklan produk sektor perbankan juga lebih tinggi dari pada sektor lain. Meski demikian, modal ventura sebagai produk IKNB justru menempati urutan pertama pelanggaran sepanjang 2017.

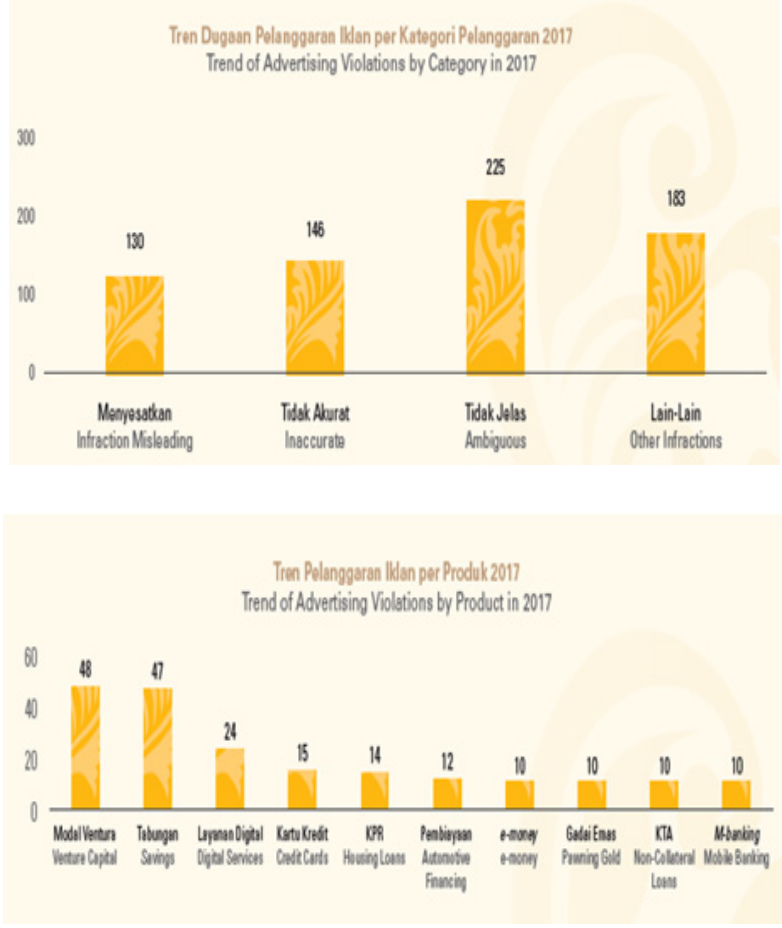

\section{Temuan Penelitian}

Dari hasil penelitian, ditemukan beberapa hal terkait dengan peranan OJK Regional 3 Jateng-DIY sebagai Muhtasib dalam melakukan pengawasan terhadap lembaga keuangan syariah (LKS) baik bank maupun non bank, antara lain:

Pertama, OJK Regional 3 Jateng DIY yang membawahi Kantor OJK Perwakilan Semarang, Tegal, Purwokerto, Solo dan Yogyakarta hanya diberikan wewenang melakukan pengawasan terhadap LKS yang berkantor pusat di wilayah Jawa Tengah dan Yogyakarta, adapun LKS yang tidak berkantor pusat di Jawa Tengah dan Yogyakarta pengawasannya menjadi domain OJK Pusat di Jakarta.

Kedua, OJK Regional 3 Jateng DIY melakukan edukasi perlindungan konsumen sejauh dalam hal tugas pokok dan fungsi OJK di wilayah Kantor Regional 3 Jawa TengahD.I.Yogyakarta.

Ketiga, terkait dengan pelaksanaan Undang-Undang Nomor 1 tahun 2013 tentang Lembaga Keuangan Mikro yang mana dalam aturan peralihan Pasal 39 ayat 1 dan 2, disebutkan bahwa Baitul Maal wa Tamwil (BMT) wajib memperoleh ijin usaha dari OJK. Namun demikian OJK belum mampu berikan sikap atau sanksi terhadap BMT yang belum 
memiliki ijin usaha dari OJK. Sehingga dengan demikian belum ada kepastian dari aturan peralihan sebagaimana terdapat dalam Pasal 39 UU LKM tersebut. Oleh karenanya ini menjadi pekerjaaan rumah bagi OJK untuk terus mensosialisasikan regulasi-regulasi terkait dengan eksistensi LKM sehingga kedepan OJK mampu memainkan peranannya sebagai regulator serta melakukan pengawasan secara maksimal dalam rangka mencegah terjadinya pelanggaran atau bahkan tindak pidana yang dapat merugikan masyarakat dan perekonomian negara.

Keempat, salah satu fungsi OJK adalah melakukan penindakan terhadap tindak pidana yang dilakukan oleh pengurusan lembaga keuangan, termasuk lembaga keuangan syariah. Temuan penelitian ini, menunjukkan bahwa di Jawa Tengah dan D.I.Yogyakarta relatif tidak banyak ditemukan kasus yang melibatkan pengurusan dalam LKS, tercatat pada tahun 2018 hanya satu LKS berbentuk bank syariah yang diduga kuat melakukan tindak pidana perbankan syariah, beruba pembiayaan fiktif yang dilakukan oleh Direksi sebuah Bank Pembiayaan Rakyat Syariah (BPRS) di Yogyaarta. Kasus ini merupakan tindak lanjut dari hasil penyidikan OJK yang kemudian diteruskan ke aparat penegak hukum (APH) dan kemudian dilakukan proses peradilan

\section{KESIMPULAN}

Dari uraian hasil penelitian dan beberapa temuan yang ada, dapat disimpulkan sebagai berikut:

Peranan Otoritas Jasa Keuangan (OJK) Wilayah Regional 3 Jawa Tengah dan D.I.Yogyakarta sebagai lembaga Muhtasib dalam mengawasi industri keuangan syariah di wilayah Jawa Tengah dan D.I.Yogyakarta cukup siginifikan, meskipun dengan beberapa catatan, diantaranya adalah posisi OJK Regional 3 Jawa Tengah dan D.I.Yogyakarta yang hanya mampu menjangkau lembagalembaga keuangan syariah (LKS) yang kantor pusatnya berkedudukan di Jawa Tengah dan D.I.Yogyakarta sementara LKS yang hanya memiliki kantor cabang di wilayah Jawa Tengah dan D.I.Yogyakarta bukan merupakan kewenangan OJK Regional 3 Jawa Tengah dan
D.I.Yogyakarta, artinya itu merupakan ranah kewenangan OJK Pusat di Jakarta. Kendalanya jika terjadi suatu pelanggaran atau perbuatan yang melawan hukum, maka OJK Regional 3 Jawa Tengah dan D.I.Yogyakarta hanya bersifat melaporkan atau berkordinasi dengan OJK Pusat.

Otoritas Jasa Keuangan (OJK) Wilayah Regional 3 Jawa Tengah dan D.I.Yogyakarta telah melakukan fungsinya sebagai penindak dalam konteks terjadi pelanggaran hukum atau tindak pidana, di mana OJK telah memainkan fungsi sebagai penyidik untuk kemudian dilaporkan ke aparat penegak hukum (APH) dan diteruksan kepada proses peradilan. Namun demikian terkait dengan implementasi Undang-Undang Lembaga Keuangan Mikro, OJK belum mampu melaksanakan fungsinya sebagai penindak dalam konstek menegakkan Pasal 39 UU LKM terkait eksistensi BMT di masyarakat yang seharusnya tundak dan patuh pada regulasi perijinan dibawah OJK.

\section{DAFTAR REFERENSI}

Akram Khan, Muhammad. 1982. Al-Hisba and the Islamic Economy, dalam Holland, Muhtar. 1982, Public Duties in Islam the Institution of the Hisbah, The Islamic Foundation, London

Al-Shaykh al-Imam Ibn Taymiya, 1982. Public Duties in Islam, The Institution of the Hisba, diterjemahkan oleh Muhtar Holland, The Islamic Foundation, London

Dwidjowijoto dkk, 2008. Ombudsman Kota Makasar, Partnership dan Pemkot Makasar, Makasar

Iwan Triyuwono, 2006. Perspektif, Metodologi dan Teori Akuntansi Syariah, Rajawali Press, Jakarta

Johan Arifin, 2008. Dialektika Etika Islam dan Etika Barat dalam Dunia Bisnis, dalam Jurnal MILLAH. Vol.VIII, No.1, FIAI UII, Yogyakarta

K. Bertens, 2000. Pengantar Etika Bisnis, Kanisius, Yogyakarta

Kedaulatan Rakyat 2 Juli 2009, Kompas, 15 Januari 2010

M. Sayuti Enggok, 2004. Profesionalisme Dunia Bisnis yang Berlandaskan Etika Menuju Indonesia Baru, dalam Jurnal Delegasi, No.3 Desember 2004, LIPI, Jakarta 
Niki Lukviarman, 2004. Etika Bisnis Tak Berjalan di Indonesia: Ada Apa dalam Corporate Governance?, dalam Jurnal SIASAT BISNIS, No.9, Vol.2, Padang.

R.A Rosyadi dan Ngatino, 2002. Arbitrase dalam Perspektif Islam dan Hukum Positif, Citra Aditya, Bandung,
Sri Haryani dan Imam Subkhan, 2006. Pedoman Prinsip dan Penilaian Bisnis Beretika Berkelanjutan, LOS DIY, Yogyakarta

Umer Chapra, 2000. Islam dan Tantangan Ekonomi, Gema Insani Press

Wawancara dengan Ibu Nita, Bagian Data OJK Regional 3 Jawa Tengah-D.I.Yogyakarta, Desember 2018 